NASA Technical Memorandum 89847

\title{
Conceptual Design and Integration of a Space Station Resistojet Propulsion Assembly
}

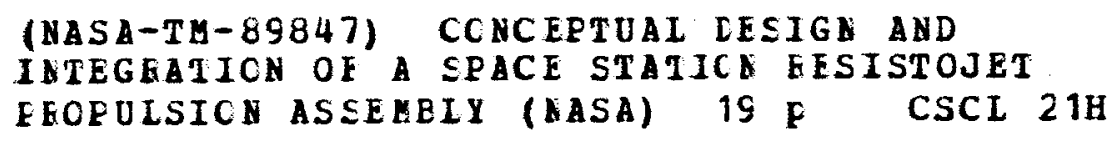

N87-20378

Unclas

G3/20 45226

Robert R. Tacina

Lewis Research Center

Cleveland, Ohio

Prepared for the

23rd Joint Propulsion Conference

cosponsored by the AIAA, SAE, ASME, and ASEE

San Diego, California, June 29-July 2, 1987 
Robert R. Tacina

National Aeronautics and Space Administration

Lewis Research Center

Cleveland, Ohio 44135

\section{ABSTRACT}

The resistojet propulsion module is designed as a simple, long life, low risk system that offers operational flexibllity to the Space Station Program. It can dispose of a wide variety of typical Space Station waste fluids by using them as propellants for orbital maintenance. A high temperature mode offers relatively high specific impulse with long life while a low temperature mode can propulsively dispose of mixtures that contain oxygen or hydrocarbons without reducing thruster life or generating particulates in the plume. A low duty cycle and a plume that is confined to a small aft region minimizes the impacts on the users. Simple interfaces with other space Station systems facilitate integration. It is concluded that there are no major obstacles and many advantages to developing, installing, and operatíng a resistojet propulsion module aboard the Initial Operational

Capability (IOC) Space Station.

\section{INTROOUCTION}

This report describes a conceptual design of a resistojet propulsion module, including an approach to its integration into the Initial operational Capability (IOC) Space Station.

The initial space Station reference configuration consisted of a single hydrazine propulsion system. 1 Subsequent trade studies resulted in a gaseous hydrogen/oxygen high thrust system and a low thrust multipropellant resistojet system as the baseline propulsion systems. ${ }^{2}$ System trade studies have shown that a resistojet propulsion system that uses a wide variety of excess fluids expected to be present on board the Space Station offers substantial cost savings, 2,3 cost savings can be realized using excess fluids in resistojets by eliminating or reducing propellant resupply for aititude maintenance and reducing the logistics problems and costs associated with disposing of these excess fluids. The resistojet system utilizes waste fluids from Space Station systems such as the Environmental Control and Life Support System (ECLSS), Manufacturing and Technology Laboratory (MTL), etc.

Resistojets have been used in many spacecraft applications in the past.4,5 In these applications, high-performance hydrazine resistojets have generally been used. For the space station application the use of resistojets with excess fluids will require an emphasis on a multipropellant capability and long life characteristics. To provide this technology an Advanced Development Program was put in place in 1985 and is successfully addressing the life, compatibility, and performance issues. 6,7

This report considers the design of the resistojet module and its integration into the space station. The objectives of the resistojet system design are: provide impulse for the Space
Station altitude maintenance, use the maximum amount of excess flutds, have long life so as to minimize replacement, and also minimize impact on the Space station environment. This report provides: a brief description of the requirements and the waste fluid avallability, a description of the resistojet system, and finaliy a discussion of the integration. A detalled description is provided in Ref. 8.

\section{REQUIREMENTS}

The following considerations and requirements were used in this design study of the resistojet system:

Multipropellant capability. It is beneficial to use as many waste fluids as possible for propulston. This reduces the propellant resupply and the logistics problems of disposing of these fluids. The capability to use oxidizing, reducing, and inert gases and steam is desirable since these gases will be avallable.

Power. A peak power of $2 \mathrm{~kW}$ was assumed for the resistojet system. This seemed appropriate based on the power allotment for propulsion for a hydrazine system which was $1 \mathrm{~kW}$ average power. 1 The average resistojet power will be less than one-fourth the peak value (see the power section). Based on the assumed $2 \mathrm{~kW}$ power limitation a module of four $500 \mathrm{~W}$ resistojets was used for this study.

Function - altitude maintenance. The resistojet propulstion system is a low thrust system, approximately $80 \mathrm{mlb} / \mathrm{thruster}$, that can provide impulse for the altitude maintenance of the Space station. A high thrust system, approximately 25 lbf/thruster, is required to perform all reaction control/attitude control functions, and collision avoidance. If there are insufficient waste fluids for the resistojet system to satisfy the altitude maintenance requirements the high thrust system will supply the remaining impulse requirements. The total impulse requirements for the altitude maintenance of the Space Station may be between 12 milition $1 \mathrm{~b}-\mathrm{sec}$ for a constant altitude of $250 \mathrm{n} \mathrm{mi}$ and 61 million lb-sec for a varying altitude (constant drag) that depends on the density of the amblent atmosphere, Table I.

Life. The impulse requirements represent 11 fetimes far greater than present resistojets have been required to meet. A goal $10000 \mathrm{hr}$ or 2 million lbf-sec was set for the life of each resistojet, which is the same impulse goal as that of the hydrogen/oxygen thrusters. This goal appears to be reasonable based on data of similar heaters used in the glass industry.?

Assembly. The goal was to keep the Extravehicular Activity (EVA) assembly time to a minimum.

Induced external environment. If the resisto jet is operated during payload viewing operation. 
the plume must be controlled for all effluents so that the molecular number column density along any line of sight does not exceed levels that are detrimental to sensitive payloads. Similarly, there are also particulate background and molecular deposition requirements.

\section{WASTE FLUIDS}

The integrated Waste Fluid System (IWFS) is responsible for collecting, treating, and storing the waste fluids that will be used in the resistojet system, see Fig. 1. A detail discussion of the waste fluids can be found in Ref. 10. Sources of waste fluids identified to date include the Shuttle scavenging, ECLSS, MTL, the Japanese and Columbus module laboratortes, and Attached Payloads.

The MTL, with up to 14 experimental facilities operational at the IOC, and the international modules will produce varying amounts of excess flulds. Amounts of waste fluids generated by these modules are dependent on the complement of exper 1ments being performed and on the amount of Space station crew time spent performing the experiments. Contaminants and associated concentration levels contained in the produced fluids are unavallable at this time. It is therefore assumed that until better contaminant information is avallable that the waste fluids will be cleaned sufficiently to allow for safe, long term storage and also for use in the resistojet propulsion system.

Attached Payload waste gases result from both purging of the experiments and cryogenic boiloff. To avoid venting and its assoclated external contamination impacts, these gases must be collected and stored. These relatively clean gases may then be used to meet other Station requirements (e.g., MTL or propulsion) or be recycled for reuse by the attached payloads where feasible. Attached payload waste gases vary greatly as a function of time in their types and amounts due to relatively short run times at the Station (typically 7 to $4 \mathrm{yr})$. An attached payload complement scheduled for operation at or near IOC which require and generate gases 1s: the Cosmic Ray Nuclei Experiment, the Solar Terrestrial Observatory, the Long Term Cryogenic Storage, and the Active Optic Technology.

Table 2 summarizes the overall space Station waste gas inventory for IOC and growth. The growth predictions are based on the station growing from one-half milition $1 \mathrm{~b}$ at IOC to one milition lb after $10 \mathrm{yr}$ and 2 crew member added every 2 yr from 8 crew members at IOC to 18 at IOC +10 years. Japanese and Columbus Labs waste gas output is assumed constant for the $10 \mathrm{yr}$ period. Attached Payload growth predictions are based on Station mass growth starting with the above four waste fluid-generating payloads. The amounts of excess water (if any) are not included since many options that affect the water balance have not been defined, e.g., the ECLSS process or water avallable from Shuttle scavenging.

\section{RESISTOJET PROPULSION SYSTEM}

A resistojet propulsion system design, system hardware, operation, and integration are described.

\section{System Schematic}

Figure 2 is a schematic of the resistojet assembly which incorporates the capability to use both waste water and gases. The resistojet assembly consists of thrusters, power controllers, fluid and electrical lines, latch valves, pressure regulators, check valves, filters, water vaporizers, and related instrumentation. This assembly consists of two redundant subassemblies with each subassembly being an orbital replacement unit (ORU). The resistojet assembly plus the hydrogen/ oxygen assembly make up the reboost module.

oxidizing gases, nonoxidizing gases and water are supplied to the resistojet system from the Integrated Waste Fluid System. The fluids are assumed to be usable for the resistojets without further processing. A filter is used downstream of the fluid connection to prevent any debris in the fluid lines from entering the resistojet system. Flow control of the gases is with a pressure regulator set at a pressure of 40 psla which is based on heating the nominal gas composition shown in Table 2 . The water flow is controlled by the pumps in the Integrated water system and is vaporized before being sent to the resistojets. After passing through isolation valves located with each resistojet, the fluid then enters one or more resistojets where it is heated and expelled propulsively.

\section{Resistojet Propulsion Subassembly Layout}

The Resistojet Propulsion subassembly consists of a bank of four resistojets, see Fig. 3.11 Two redundant subassemblies comprise an assembly. The resistojet assembly is attached to a long boom or stinger that extends out past the laboratory modules. The assembly also includes micrometeoroid and thermal shielding (not shown in the assembly drawing).

Two 1/4-in. (outside diameter) fluid lines from the nonoxidizing waste fluids storage system, two $1 / 4-1 n$. fluid lines from the oxidizing waste fluids storage system and two $1 / 8-1 n$. water lines are routed along the boom to the resistojet propulsion assembly. The lines are manifolded together so that each resistojet can be supplied with any of the waste fluids.

\section{Parts List and Weights}

A parts count and weights for the resistojet system is given in Table 3 . Included are the two operational orbital replacement units and a spare unit stored aboard the Space Station. 11 Oniy three ftems in the 1ist, the resistojet thruster. power control unit, and water vaporizer, require development for the Space Station application. The resistojet and the power control unit are discussed below. The issue with the vaporizer is long life since the effect of zero gravity in space should not be a factor.

\section{Untque Components}

Multipropellant resistojet. The thruster heater and heat exchanger are fabricated primarily from platinum. The multipropellant resistojet will be able to provide cold-gas flow, warm-gas flow to prevent condensation in the exhaust, and high temperature flow for increased performance. 
The Engineering Model resistojet thruster described here was designed under a NASA Lewis Advanced Development Program contract and a detalled description is given in Ref. 12. The major thruster components are shown in Fig. 4. The heat exchanger is centraliy located and of a pleated design. The gases are heated by a platinum sheathed heater which has heritage from the commercial glass industry. The resistojet $11 \mathrm{fe}$ and multipropellant capability has been demonstrated by compatibility tests with typical waste fluids from space Station systems such as $\mathrm{CO}_{2}, \mathrm{CH}_{4}, \mathrm{H}_{2} \mathrm{O}$, $\mathrm{H}_{2}$ and $\mathrm{O}_{2} .{ }^{7}$ The heated gas is expanded out in conventional cone shape nozzle that flairs through a trumpetshape nozzle with a plume deflector to confine nearly all of the flow in the forward direction. The heater, heat exchanger, and nozzle are thermally isolated by using multilayer radiation shields. The temperature of the outer housing of the resistojet assembly is predicted to be less than $300{ }^{\circ} \mathrm{C}$. The basic resistojet is designed with a $500 \mathrm{~W}$ heater that can provide thrust levels from 20 to $200 \mathrm{mlb} .13$ Table 4 shows the specific impulse and thrust as a function of flow rate and power for various space station waste flulds. The mixed gas is based on a homogenous mixture of the 1995 IOC gases shown in Table 2.

Resistojet power controller. The purpose of the controller is to regulate the current flow to the resistojet heater during start-up and steady state operation while power matching the heater to a high voltage power bus. The resistojet heater has a very low resistance $(0.35 \Omega)$ at ambient temperature and the resistance increases by about a factor of three at the maximum operating heater temperature $\left(1400^{\circ} \mathrm{C}\right)$. The controller's primary function is to avoid excessive current spikes at start-up and ensure that the maximum heater temperature is not exceeded by maintaining the heater resistance within an acceptable limit. A $20 \mathrm{kHz}$ power controller for use in development studies has been designed and built and is described in Ref. 14.

\section{SYSTEM OPERATION}

Three modes of operation are possible with the resistojet power controller discussed above. The first mode is a high temperature mode in which the gases are heated using the maximum heater temperature of about $1400{ }^{\circ} \mathrm{C}$ which still provides long life. Note that the high temperature in this mode is still relatively low compared to temperatures of $1900{ }^{\circ} \mathrm{C}$ in high performance hydrazine resistojets. The second mode is a warm gas mode in which the gases are heated to between 300 and $500{ }^{\circ} \mathrm{C}$. Heating above $300{ }^{\circ} \mathrm{C}$ is desired to prevent condensation of gases in the exhaust. Heating to less than $500{ }^{\circ} \mathrm{C}$ is desired to prevent cracking of hydrocarbons when significant amounts of these are present in the waste gases. For long 1 ife, mixtures containing oxygen would also be used in this mode. The high temperature mode provides 60 percent more impulse than the warm gas mode and would be used whenever possible assuming the maximum impulse is required for altitude maintenance. Finaliy, a third mode is a cold gas mode in which the gases are not heated at all. The cold gas option is not considered further because of the problem of condensation in the exhaust, e.g., water vapor or carbon dioxide condensation.
This flexibility in operation gives resistojets the capability to use oxidizing, reducing, and inert gases plus the use of water as steam. There is also synergism with the hydrogen/oxygen system since the water supplied to the hydrogen/ oxygen electrolyzer or the hydrogen and oxygen from the electrolyzer could be used as propellant for the resistojet.

\section{Waste Gas Impulse}

The impulse available from the waste gases is shown in Table 5 . Using the maximum impulse from the high temperature mode, the total $10 \mathrm{yr}$ impulse can range from 10 million $1 \mathrm{bf}-\mathrm{sec}$ (gases with Bosch option) to 15 million $1 \mathrm{bf}-\mathrm{sec}$ (gases with Sabatier option). The reboost impulse requirements range from 12 to $60 \mathrm{million} 1 \mathrm{bf}-\mathrm{sec}$ total 10 year impulse depending on which operating altitude scenario is used (see Table 1). Thus, resistojets can provide a significant percent of the reboost requirements depending on which options are chosen. The proportion of time using the high temperature mode or warm gas mode will also be determined by waste gas compositions. The amount of water used through the resistojets is not defined at present and will depend on the water avallability and the needs of the hydrogen/oxygen system.

\section{Duty Cycle}

Important considerations in determining the duty cycle are the user needs. Some attached payload users have requirements that mandate reducing contamination of the external environment to a minimum. For such users there may be advantages to operating the resistojet thrusters a small fraction of the time. Two reasons can be cited for operating at a low duty cycle. First the off time represents quiet, optimum conditions for viewing in all directions. Secondly, if for any reason a payload user felt the need to protect a sensitive surface during operation, a low duty cycle would minimize the time that his instrument was covered and inactive. There is evidence that astronomical and earth viewing can continue during resistojet operation since for most viewing angles, the contamination requirements expressed in terms of column density and deposition rates will not be exceeded.

In determining the minimum duty cycle that can be achieved, one must consider the power requirements. Figure 5 shows duty cycle versus peak power using only the IOC waste gases. With $2 \mathrm{KW}$ as the peak power the duty cycle using the IOC waste gases is 12 percent. Note that the total energy level or average power used by the resistojet does not change, fust the peak power.

For a semi-continuous duty cycle, the period of the duty cycle also has to be determined. Examples of possible periods are one orbit, one shift, one day, or one week. As space Station user needs and operations become better defined, reasons for a definite duration length may emerge. Aperiodic operation is also possible. A possible reason for aperlodic operation is to accommodate a microgravity experiment. Using a variable control the resistojet thrust could exactiy balance Space station drag to reduce the gravity environment. 
Operational Scenarto

Operation of the resistojet module is through the Guidance Navigation and Control System. Upon command, appropriate latch valves are opened, the water vaporizer is activated, if necessary, and the resistojet heater is activated through the controller.

An operational sequence and timeline for resistojet start-up, based on a transient analysis for the nominal waste gas composition, is shown in Fig. 6. A timeline for resistojet operation with water is given in Ref. 8 . The power is turned on prior to opening the flow valve to reduce the transient time and to preclude injecting cold gas into the environment. The time for the heat exchanger to reach 95 percent of the steady state temperature without flow is $610 \mathrm{sec}$. Thrust is initiated at approximately 95 percent of steady state temperature, which corresponds to approximately 97.5 percent of steady state specific impulse. The thrust level at start-up is the same as the steady state value, because the decrease in specific impulse is offset by the increase flow at the lower gas temperature for a pressure regulated feed system. The resistojet run valves are opened approximately one second after opening of the storage subsystem valve. This is sufficient time to $\mathrm{f} 111$ the $60 \mathrm{ft}$ of $1 / 4-i n$. diameter tubing. After the valves are opened an additional $200 \mathrm{sec}$ is requited to reach steady state temperature.

The shutdown sequence is initiated by turning off the storage subsystem valve. For the supply line pressure to drop below the regulator operating pressure takes approximately $60 \mathrm{sec}$. The power to the resistojet is then turned off. The relatively high heat capacity of the heater results in only a small decrease in exit gas temperature of approximately $10^{\circ} \mathrm{C}$ as the residual gas is vented. After an additional $30 \mathrm{sec}$, the pressure in the tubing will decay to less than 0.4 psia. At this time, the resistojet if operating with a reducing gas could be restarted and operated with an oxidizer fluid without reaction because of the low partial pressure of the reducing gas in the supply line.

\section{SYSTEM INTEGRATION}

The resistojet propulsion module will have interfaces with at least four distributed systems; Data Management, Guidance Navigation and Control, Power. Waste Fluid Management, and possibly Therma 1.

DMS and GN\&C. Operational commands from Guidance Navigation and Control will be delivered to a local Data Management bus via a Network Interface Unit/Bus Interface Adapter. A Multiplexer Demultiplexer (MDM) will be the junction of the local bus and the resistojet's various components. The MDM will receive condi-tioned voltage and current signals from the resistojet heater element, line pressures, valve position, and water vaporizer current, pressure, and voltage. These signals will be passed through the DMS to GN\&C for actuation of the systems.

Power system. Power will be supplied to the Remote Power Controller, and to the water vaporizer from the Space Station power bus. Currently the resistojet heater element could operate at $440 \mathrm{Vac}$ (or $220 \mathrm{Vac}$ ) and $20 \mathrm{kHz}$, or on a high voltage dc supply. The power required to operate valves and other sensors is expected to be low voltage dc supplied from a dc bus.

Waste fluid management system. Fluids will be supplied to the resistojet module from storage tanks. These fluids will consist of nonoxidizing gas mixtures, waste water, and possibly oxidizing gases.

Thermal control system. Design iterations are still ongoing to determine possible interfaces with this system. None have been identified at this time.

\section{Power Usage}

The power required by the resistojets consists of the power for controlling values and operating the heating element of the resistojets. The power required by the resistojet system is dependent on the fluid types and amounts, and the operating point of the resistojets. The power required shown in Table 6 reflects the gases in Table 2 heated to obtain maximum impulse. These power usage numbers reflect the maximum power that will be needed by resistojets. If the impulse that is avallable from the waste gases is greater than what is needed, the resistojet will be run at a lower operating point. This translates into reduced power consumption.

\section{Assembly and Location}

A reboost module will consist of a resistojet thruster assembly and a hydrogen/oxygen thruster assembly. 15 a possible reboost module configuration is shown in Fig. 7. The thrusters are on a stinger or truss that can be extended as the Station is assembled, see Figs. 7 and 8 . The stinger could be self deployable as was the unit flown on the Solar Flight Experiment aboard STS $41-0.16$

The location of the reboost stinger is through the geometric center of the Station which should be nearly through the center of gravity. This is important when considering the torques imposed upon the station, even those as small as the ones created by the resistojets. Potential impingement of the plume upon the modules or the Japanese experiments porch is not a problem using an extendable boom as shown.

\section{Plume Analysis}

The multipropellant resistojet propulsion module will use a variety of gases, some more benign to observers and Space Station sensitive surfaces than others. In the clean category are hydrogen, nitrogen, oxygen, and hellum, which are all relatively infrared inactive and condense at very low temperatures. The more infrared active molecules include methane, carbon dioxide, and water, which also condense at higher temperatures than the benign fluids listed above. Whatever the propellant may be, the resistojet will exhaust it in the aft region at temperatures low enough to avoid dissociation and high enough to preclude condensation and at velocities around $1 \mathrm{~km} / \mathrm{s}$ opposite to the space station velocity vector.

Particulate background. Resistojet operating conditions (i.e. chamber pressure and temperature) 
and short nozzle length (less than an inch) preclude condensation in the nozzle, based on onedimensional isentropic expansions analysis. Beyond the nozzle extt, the collision frequency decreases rapidiy and condensation is less probable than in the nozzle.

Molecular column densities. Molecular column density is calculated by integrating the number density (number of molecules of a particular specles per unit volume) along a specified line of sight. In order to perform this calculation, the density field produced by the resistojet must be known. A modified version of Simons' method for calculating far field plume structure was used to obtain an equation for the density field, 17 which was integrated along lines of sight originating from the center of the upper boom of the dual keel reference configuration. The results of this process for a resistojet with a nozzle half angle of $10^{\circ}$ using the nominal IOC gas mixture and operating at a thrust level of $0.050 \mathrm{lbf}$ is given in Fig. 9 . This figure shows the variation in number column density with line of sight angle $\left(0^{\circ}\right.$ is looking forward and $90^{\circ}$ is the zenith line of sight). Also shown are the coilumin density requirements. The limits are not exceeded until the line of sight originating from the center of the upper boom passes near where the resistojet is located, presumably a seldom used viewing direction. Therefore, the area of concern for observing experiments is the aft-looking lines of sight which comprise only about 3 percent of the total solid viewing angle. Observations in the aft direction can be easily accommodated due to the relatively low duty cycle.

Preliminary results obtained from quartz crystal microbalance measurements of a $\mathrm{CO}_{2}$ plume in a NASA Lewis vacuum tank facllity indicate that the modified Simons' model plume density predictions agree well with QCM data to within a factor of five for the points in which data were collected.18 This gives credibility to the estimated order of magnitude accuracy of the column density level calculations.

Molecular deposition. Molecular deposition from propulsion system effluents can result from direct source-to-surface transport or from return flux. Return flux occurs when the propulsively emitted molecules impinge on a surface due to collisions with the ambient molecules. Preliminary calculations for return flux indicates a very low return flux from resistojet thrusters, approximately $10^{7} \mathrm{molecules} / \mathrm{cm}^{2} / \mathrm{sec}$. This level should not be a problem. More work needs to be done in modeling of the return flux mechanism, and deposition and re-evaporation calculations.

\section{Maintenance}

There is no scheduled maintenance required for the resistojet module. If a fallure occurs such that one thruster is entirely inoperable, the remaining thrusters in that bank of four will provide adequate redundancy. Since the heater element of each resistojet is designed to operate well in excess of $10000 \mathrm{hr}$, the frequency of heater fallures should be minimal. The installation is designed for replacement of a subassembly containing four resistojets.

\section{CONCLUSION}

Resistojets have been selected by the Space Station Program office to satisfy a large percentage of the reboost propulsion requirements and to serve as an effective means of waste fluid management control. The sources of waste fluids include Shuttle scavenging, the Environmental Life Support System, laboratory modules, and Attached Payloads.

This report presents an engineering conceptual design for the Resistojet Propulsion Module and an integrated system analysis. The resistojet module will be designed as a simple, long life, low risk system capable of using multipropellants typical of Space Station waste fluids. Component technology has been successfully demonstrated in the Advanced Development Program and form a strong basis for the next phase of applied development and construction. The system offers operational flexiblitity both in the disposal of these gases and their use as a propellant. Reducing gases, oxtdizing gases, inert gases and water (used as steam) can be utilized. Two operating modes are proposed; a high temperature mode for relatively high spectific impulse with long life, and a second low temperature mode that propulsively disposes of mixtures that contain oxygen or hydrocarbons without reductions in thruster life or particulates in the plume.

Simple interfaces with Data Management, Guidance Navigation and Control, Power. Thermal and fluid systems facilitate integration. The resistojet location is aft of the pressurized modules which limits the contamination effects to a small aft region and positions the thrust through the center of gravity. A low duty cycle also minimizes any impacts on users.

It is concluded that there are no major obstacles and many advantages to developing. installing and operating a Resistojet Propulsion Module aboard the IOC Space Station.

\section{ACKNOWLEDGMENTS}

Contributions to this paper by B. Heckert, L. Finden, W. Gillon, I. Korn, S. Miyata, C. Stewart, and $D$. Wheeler of Rockwell International, Rocketdyne Division, Canoga Park, CA. are gratefully acknowledged.

\section{REFERENCES}

1. "Space Station Reference Configuration Description," NASA TM-87493, 1984.

2. Minutes of the Space Station Control Board, NASA Johnson Space Center, Houston, TX, Apr. 24,1986

3. Brennan, S.M. and Donavan, R.M., "Space Station Benefits from ECLS and Propulsion System Synergism," AIAA Paper 86-1407, June 1986.

4. McKevitt, F.X., "Design and Development Approach for the Augmented Catalytic Thruster (ACT)," AIAA Paper 83-1255, June 1983. 
5. Oressler, G.A., Morningstar, R.E., Sackheim, R.L., Fritz, D.E., and Kelso, R. "Flight Qualification of the Augmented Electrothermal Hydrazine Thruster," AIAA Paper 81-1410, July 1981 .

6. Jones, R.E., "Space Station Propulsion: The Advanced Development Program at Lewis," AIAA Paper 85-1154, July 1985. (Also NASA TM-86999)

7. Morren, W.E., Whalen, M.V., and Sovey, J.S., "Performance and Endurance Tests of a Multi. propellant Resistojet for Space Station Auxiliary Propulston." AIAA Paper 86-1435, June, 1986. (Also NASA TM-87278)

8. Tacina et al., "Conceptual Design and Integration of a Space Station Resistojet Propulsion Assemb ly," NASA TM-89847, 1987.

9. Jacchla, L.G., "New Static Mode1s of the Thermosphere and Exosphere With Empirical Temperature Profiles," SAO-Specia1-Rept-313, Smithsonian Astrophysical observatory, Cambridge, MA, 1970 (NASA CR-112684).

10. Peterson, T.T., "Space Station Fluid Inventories of the Integrated Waste Fluids and Integrated Water Systems," NASA Lewis Research Center PIR-191, Mar. 1987.

11. Heckert, B.J., "Engineering Model Resistojet System, Interim Report," NASA Contract NAS3$24658,1986$.
12. Pugmire, T.K., Cann, G.L., Heckert, B., and Sovey, J.S., "A 10,000 Hour Life Multiprope1lant Engine for Space Station Applications," AIAA Paper 86-1403, June 1986.

13. Morren, W.E., Haag, T.W., Sovey J.S., "Eng1neering Model Resistojet Characterization", AIAA Paper 87-2120, July 1987.

14. Gruber, R. P., "Resistojet Control and Power for High Frequency A.C. Buses," AIAA Paper 87-0994, May 1987.

15. Findings of the Critical Evaluation Task Force, NASA Langley Research Center, Hampton, VA, Sept. 1986.

16. Crawford, R.F., "Data on Canister-Deployable Able Booms for the Space Station Photovoltaic Power Study," Able Engineering Company memo for the Ford Aerospace and Communications Corporation, Aug. 23, 1985.

17. Hoffman, D.J., "Resistojet Plume and Induced Environment Analysis," M.S. Thes 1s, Case Western Reserve University, 1987.

18. Zana, L.M., Hoffman, D.J., Breyley, L.R., and Serafini, J.S., "An Analytical and Experimental Investigation of Resistojet Plumes." AIAA Paper 87-0399, 1987. (Also NASA TM-88852).

TABLE 1. - REBOOST IMPULSE REQUIREMENTS

[Nominal atmosphere assumed (Ref. 9).]

\begin{tabular}{|c|c|c|c|}
\hline \multirow[t]{2}{*}{ Year } & \multicolumn{2}{|c|}{$\begin{array}{l}\text { Variable altitude } \\
\text { average } 0.3 \text { micro-g's }\end{array}$} & $\begin{array}{l}\text { Nominal } 250 \mathrm{nmi} \\
\text { altitude }\end{array}$ \\
\hline & $\begin{array}{l}\text { Altitude, } \\
\text { nmi }\end{array}$ & $\begin{array}{l}\text { Impulse, } \\
\text { Ibf-sec }\end{array}$ & $\begin{array}{l}\text { Impulse, } \\
\text { lbf-sec }\end{array}$ \\
\hline $\begin{array}{l}1995 \\
1996 \\
1997 \\
1998 \\
1999 \\
2000 \\
2001 \\
2002 \\
2003 \\
2004 \\
2005 \\
\\
\end{array}$ & $\begin{array}{l}189 \\
184 \\
180 \\
180 \\
180 \\
192 \\
202 \\
213 \\
221 \\
210 \\
205\end{array}$ & $\begin{array}{lll}3 & 841 & 000 \\
4 & 500 & 000 \\
5 & 054 & 000 \\
4 & 855 & 000 \\
5 & 356 & 000 \\
4 & 753 & 000 \\
5 & 275 & 000 \\
5 & 967 & 000 \\
6 & 480 & 000 \\
7 & 478 & 000 \\
7 & 621 & 000 \\
61 & 181 & 000\end{array}$ & $\begin{array}{lll} & 658 & 000 \\
& 359 & 000 \\
& 313 & 000 \\
& 278 & 000 \\
& 307 & 000 \\
& 523 & 000 \\
& 52 \\
1 & 028 & 000 \\
1 & 905 & 000 \\
2 & 646 & 000 \\
2 & 162 & 000 \\
1 & 719 & 000 \\
11 & 899 & 000\end{array}$ \\
\hline
\end{tabular}


TABLE 2. - ANNUAL WASTE GAS PRODUCTION FROM ALL SOURCES

[Assumed Bosch ECLSS, changes with Sabatier ECLSS in Parenthes is (1bm/yr).]

\begin{tabular}{|c|c|c|c|c|c|c|c|c|c|c|}
\hline Gas/year & 1995 & 1996 & 1997 & 1998 & 1999 & 2000 & 2001 & 2002 & 2003 & 2004 \\
\hline Argon & 1264 & 1264 & 1264 & 1264 & 1348 & 1348 & 1348 & 1026 & 1026 & 1109 \\
\hline $\mathrm{CO}_{2}$ & 451 & 693 & 451 & 208 & 260 & 260 & 260 & 260 & 260 & 260 \\
\hline $\mathrm{CO}_{2} / \mathrm{CH}_{4}$ & $\begin{array}{r}0 \\
(3740)\end{array}$ & $\begin{array}{c}0 \\
(3740)\end{array}$ & $\begin{array}{c}0 \\
(3740)\end{array}$ & $\begin{array}{c}0 \\
(3740)\end{array}$ & $\begin{array}{c}0 \\
(5610)\end{array}$ & $\begin{array}{c}0 \\
(5610)\end{array}$ & $\begin{array}{c}0 \\
(5610)\end{array}$ & $\begin{array}{c}0 \\
(5610)\end{array}$ & $\begin{array}{c}0 \\
(5610)\end{array}$ & $\begin{array}{c}0 \\
(7480)\end{array}$ \\
\hline Freon & 6 & 6 & 6 & 6 & 8 & 8 & 8 & 8 & 8 & 9 \\
\hline Helium & 229 & 808 & 896 & 896 & 813 & 813 & 813 & 813 & 41 & 45 \\
\hline Hydrogen & $\begin{array}{l}182 \\
(42)\end{array}$ & $\begin{array}{l}182 \\
(42)\end{array}$ & $\begin{array}{c}322 \\
(182)\end{array}$ & $\begin{array}{c}322 \\
(182)\end{array}$ & $\begin{array}{c}702 \\
(492)\end{array}$ & $\begin{array}{c}394 \\
(184)\end{array}$ & $\begin{array}{l}254 \\
(44)\end{array}$ & $\begin{array}{l}254 \\
(44)\end{array}$ & $\begin{array}{l}254 \\
(44)\end{array}$ & $\begin{array}{l}325 \\
(45)\end{array}$ \\
\hline Nitrogen & 1835 & 1989 & 1835 & 1680 & 2338 & 2338 & 2338 & 2108 & 2108 & 2765 \\
\hline oxygen & 243 & 243 & 243 & 243 & 335 & 335 & 335 & 335 & 335 & 426 \\
\hline Xenon & 88 & 88 & 88 & 88 & 110 & 110 & 110 & 110 & 110 & 132 \\
\hline $\begin{array}{l}\text { Krypton } \\
\text { Totals }\end{array}$ & 80 & 80 & 80 & 80 & 80 & 80 & 80 & 80 & 80 & 80 \\
\hline Bosch & 4378 & 5353 & 5185 & 4787 & 5994 & 5686 & 5546 & 4995 & 4222 & 5203 \\
\hline Sabatter & 7978 & 8953 & 8785 & 8387 & 11394 & 11086 & 10946 & 10394 & 9622 & 12403 \\
\hline
\end{tabular}

TABLE 3. - RESISTOJET PROPULSION ASSEMBLY COMPONENTS

\begin{tabular}{|l|c|c|c|c|}
\hline \multicolumn{1}{|c|}{ Component } & $\begin{array}{c}\text { Quantity per } \\
\text { subassembiy }\end{array}$ & $\begin{array}{c}\text { Total on } \\
\text { stationd }\end{array}$ & $\begin{array}{c}\text { Unit } \\
\text { weight, } \\
\text { lbm }\end{array}$ & $\begin{array}{c}\text { Subassembly } \\
\text { weight, } \\
\text { lbm }\end{array}$ \\
\hline Resistojet & 4 & 12 & 8.0 & 32.0 \\
Power controller & 1 & 3 & 15.0 & 15.0 \\
Latch valve & 8 & 24 & 0.4 & 3.2 \\
Check valve & 3 & 9 & 0.2 & 0.6 \\
Pressure regulator & 2 & 6 & 0.3 & 0.6 \\
Pressure transducer & 2 & 6 & 0.3 & 0.6 \\
Water vaporizer & 1 & 3 & 4.0 & 4.0 \\
Filter & 3 & 9 & 0.1 & 0.3 \\
Oisconnect & 4 & 3 & 0.4 & 1.6 \\
Manifold & 1 & 3 & 9.2 & 9.2 \\
Cables and wiring & 1 & 3 & 20.0 & 5.0 \\
Structure & 1 & 3 & 3.0 & 3.0 \\
Thermal shielding & 1 & & & 3.0 \\
Total, & & & & 168.0 \\
or per assembly & & & & \\
\hline
\end{tabular}

aone subassembly plus one redundant subassembly comprise the assembly; one additional replacement unit stored in the station. 
TABLE 4. - RESISTOJET OPERATING CHARACTERISTICS

[Mixed gases based on IOC gases excluding frean TABLE 2.]

\begin{tabular}{|c|c|c|c|c|c|c|c|c|}
\hline \multirow[t]{2}{*}{ Gas } & \multicolumn{4}{|c|}{ High temperature mode } & \multicolumn{4}{|c|}{ Warm gas mode } \\
\hline & $\begin{array}{c}\text { Specific } \\
\text { impulse, } \\
\text { sec }\end{array}$ & $\begin{array}{c}\text { Power, } \\
W\end{array}$ & $\begin{array}{c}\text { Thrust, } \\
\text { mlb }\end{array}$ & $\begin{array}{l}\text { Flow } \\
\text { rate, } \\
\text { lb/hr }\end{array}$ & $\begin{array}{c}\text { Specific } \\
\text { impulse, } \\
\text { sec }\end{array}$ & $\begin{array}{c}\text { Power, } \\
w\end{array}$ & $\begin{array}{c}\text { Thrust, } \\
\text { mlb }\end{array}$ & $\begin{array}{l}\text { Flow } \\
\text { rate, } \\
\text { lb/hr }\end{array}$ \\
\hline $\begin{array}{l}\mathrm{CO}_{2} \\
\mathrm{Nitrogen} \\
\mathrm{CO}_{2} / \mathrm{CH}_{4} \\
\text { Steam } \\
\text { Argon } \\
\text { Hydrogen } \\
\text { Helium } \\
\text { Mixed gases }\end{array}$ & $\begin{array}{l}130 \\
160 \\
140 \\
200 \\
135 \\
500 \\
425 \\
204\end{array}$ & $\begin{array}{l}500 \\
500 \\
250 \\
500 \\
500 \\
500 \\
500 \\
500\end{array}$ & $\begin{array}{r}68 \\
99 \\
80 \\
56 \\
148 \\
22 \\
52 \\
100\end{array}$ & $\begin{array}{l}1.89 \\
2.04 \\
2.00 \\
1.00 \\
3.93 \\
0.16 \\
0.44 \\
1.76\end{array}$ & $\begin{array}{r}80 \\
100 \\
100 \\
130 \\
70 \\
340 \\
220 \\
114\end{array}$ & $\begin{array}{c}20-400 \\
22-430 \\
25-300 \\
0 \\
19-380 \\
28-500 \\
18-360 \\
22-409\end{array}$ & $\begin{array}{c}9-180 \\
8-160 \\
4-80 \\
8-140 \\
10-200 \\
3-54 \\
3-60 \\
8-163\end{array}$ & $\begin{array}{l}.4-8 \\
.3-6 \\
.3-6 \\
.2-4 \\
.5-10 \\
.03-.6 \\
.05-1 \\
.3-6\end{array}$ \\
\hline
\end{tabular}

TABLE 5. - IMPULSE AVAILABLE FROM WASte GASES,

LBF-SEC/YR

\begin{tabular}{|c|cc|c|}
\hline Year & $\begin{array}{c}\text { All IOC gases } \\
\text { with Bosch ECLSS }\end{array}$ & $\begin{array}{c}\text { All IOC gases } \\
\text { with Sabatier ECLSS }\end{array}$ \\
\hline 1995 & 1757000 & 1210000 \\
1996 & 1060000 & 1500000 \\
1997 & 1110000 & 1560000 \\
1998 & 1050000 & 1510000 \\
1999 & 1340000 & 2020000 \\
2000 & 1190000 & 1870000 \\
2001 & 1120000 & 1800000 \\
2002 & 1040000 & 1720000 \\
2003 & 170000 & 1390000 \\
2004 & 880000 & 1790000 \\
Tota1 & 10257000 & 15370000 \\
\hline
\end{tabular}

TABLE 6. - POWER REQUIREMENTS FOR THE RESISTOJET SYSTEM

\begin{tabular}{|c|c|c|}
\hline Year & $\begin{array}{l}\text { All IOC gases with } \\
\text { Bosch ECLSS }\end{array}$ & $\begin{array}{l}\text { All IOC gases with } \\
\text { Sabatier ECLSS }\end{array}$ \\
\cline { 2 - 3 } & $\begin{array}{c}\text { Average } \\
\text { power, } \\
\mathrm{kW}\end{array}$ & $\begin{array}{c}\text { Average } \\
\text { power, } \\
\mathrm{kW}\end{array}$ \\
\hline 1995 & 0.198 & 0.222 \\
1996 & .291 & .315 \\
1997 & .333 & .357 \\
1998 & .323 & .347 \\
1999 & .447 & .483 \\
2000 & .359 & .395 \\
2001 & .319 & .355 \\
2002 & .302 & .338 \\
2003 & .192 & .228 \\
2004 & .239 & .287 \\
\hline
\end{tabular}




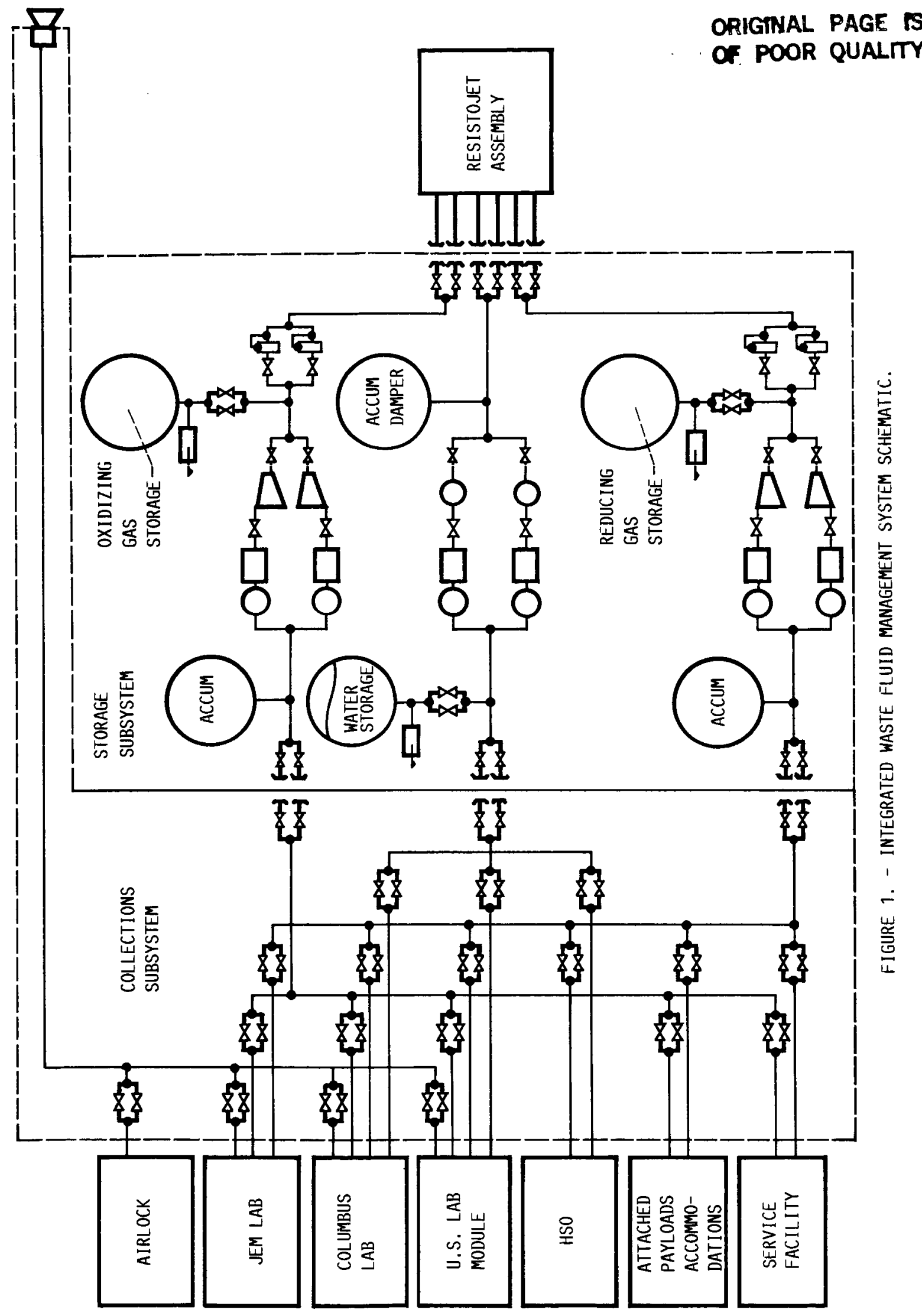




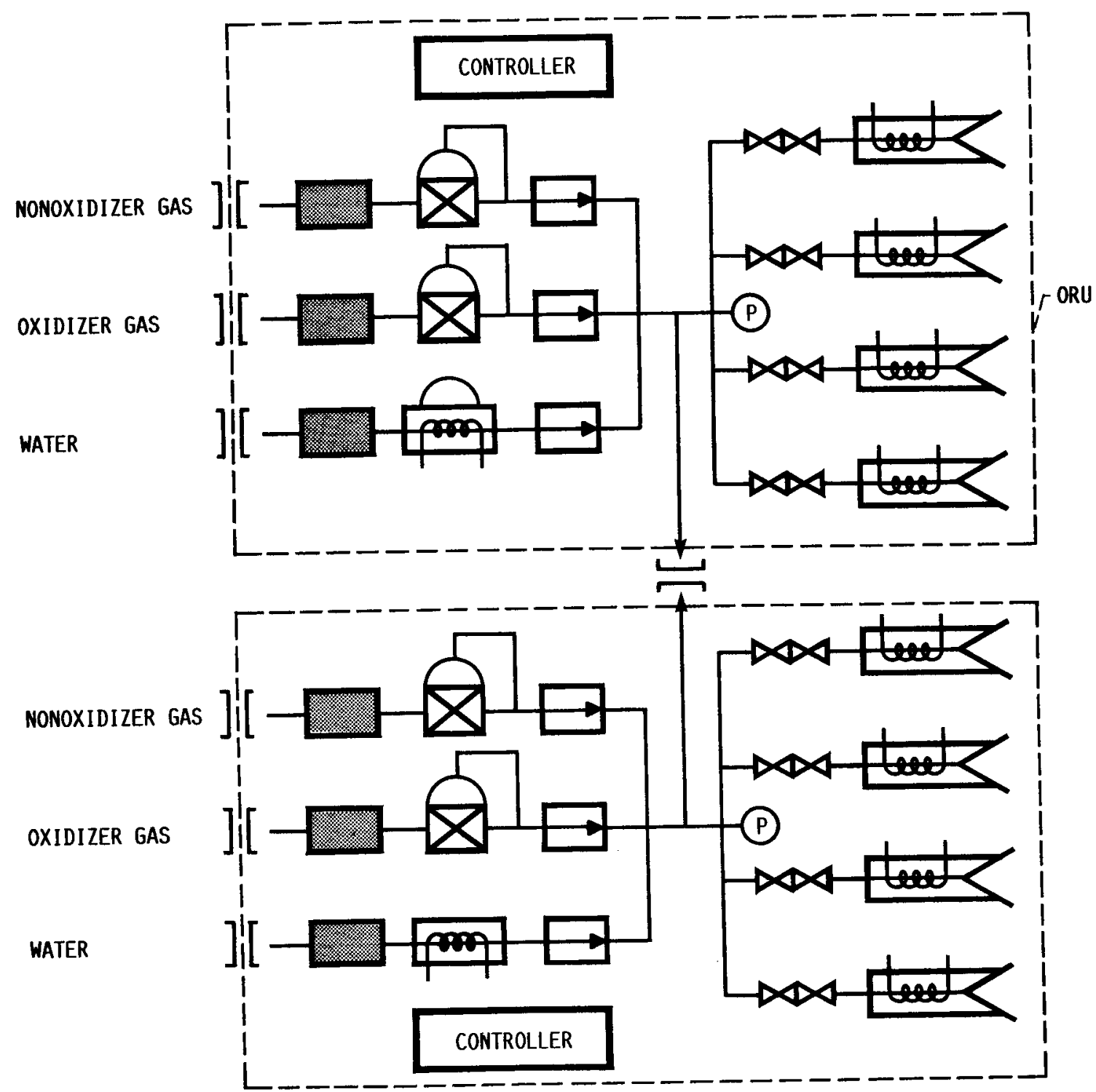

FIGURE 2. - RESISTOJET PROPULSION ASSEMBLY. 


\section{ORIGMLL PAGE is \\ OF POON QUALTY}

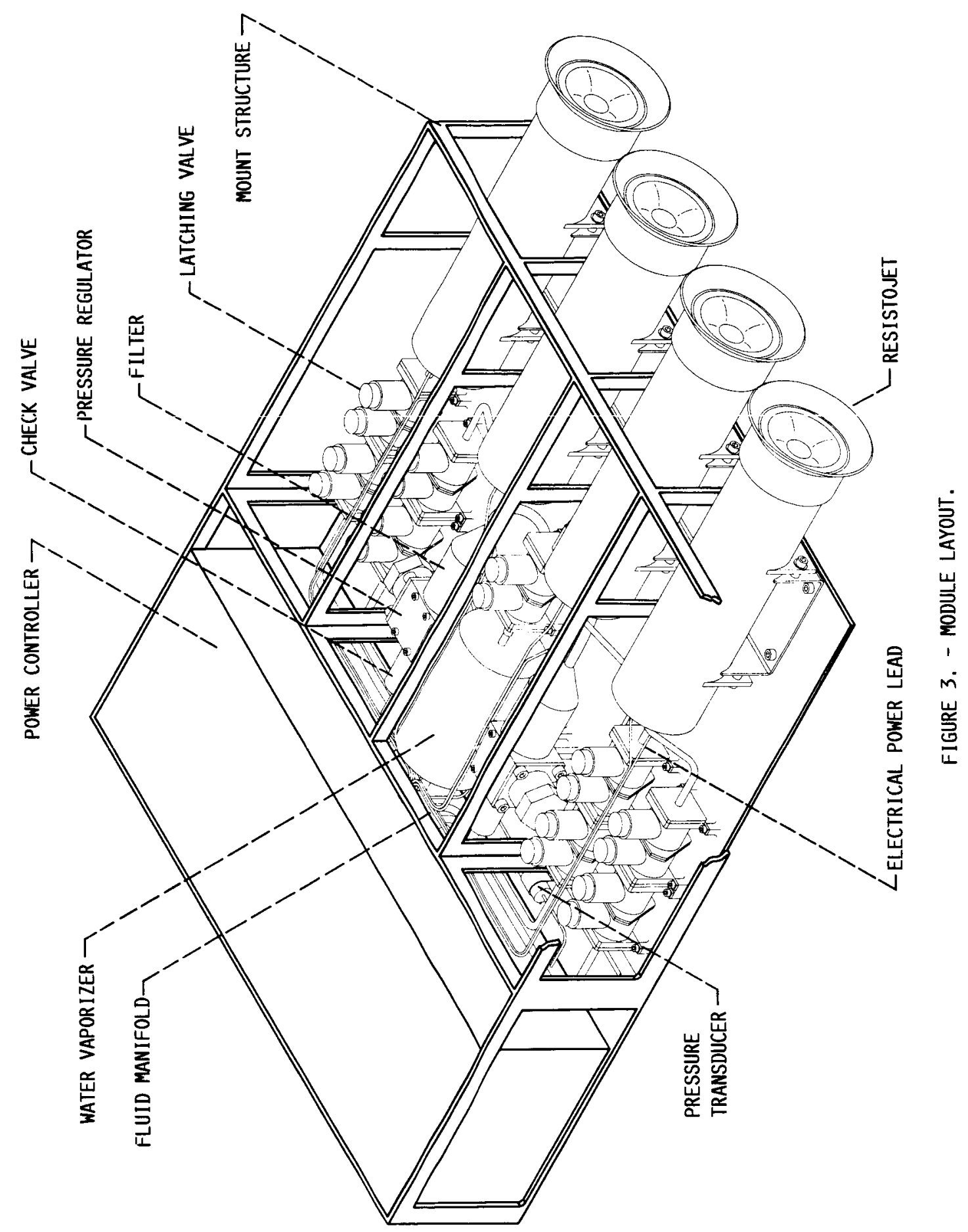




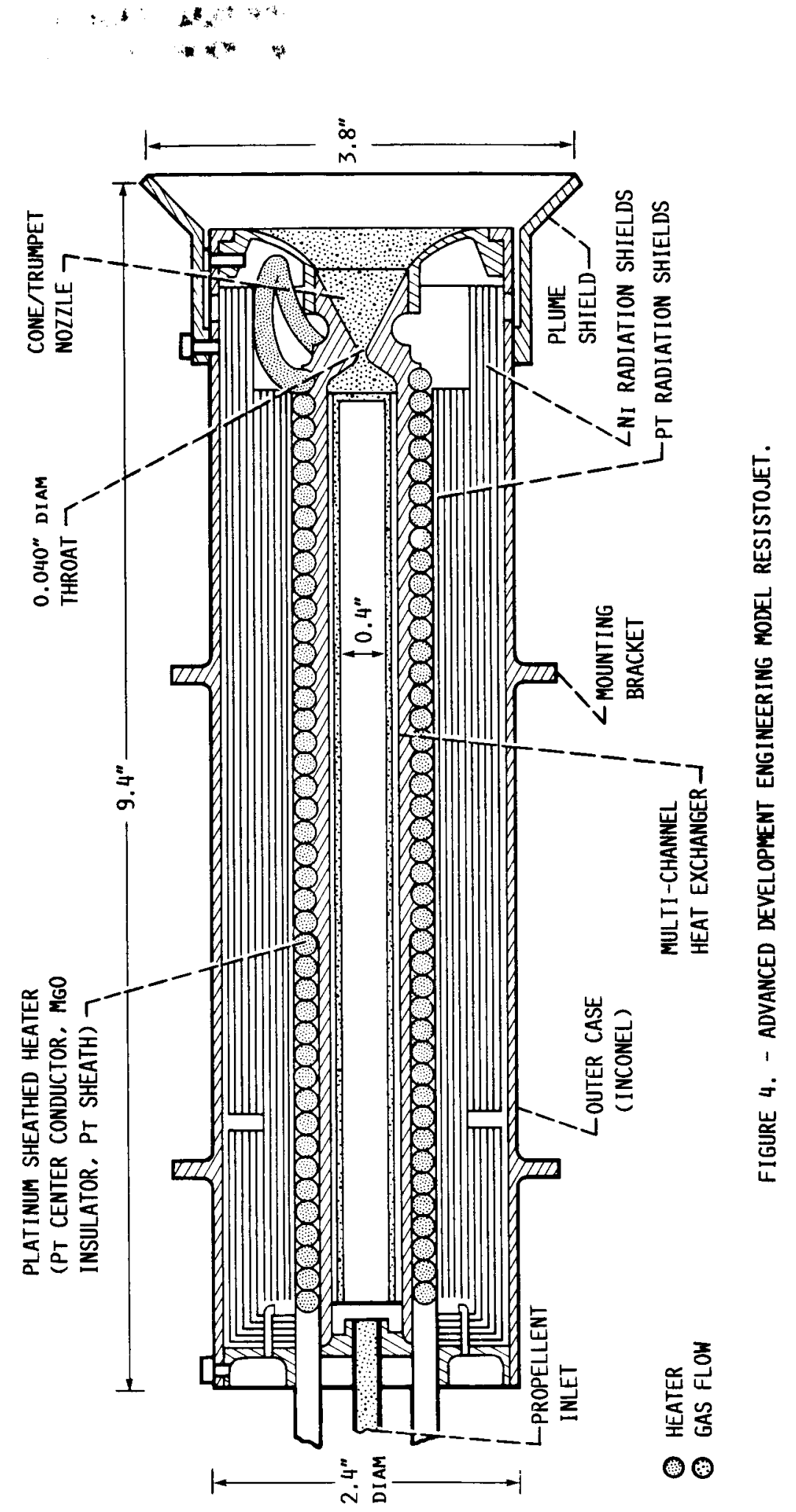




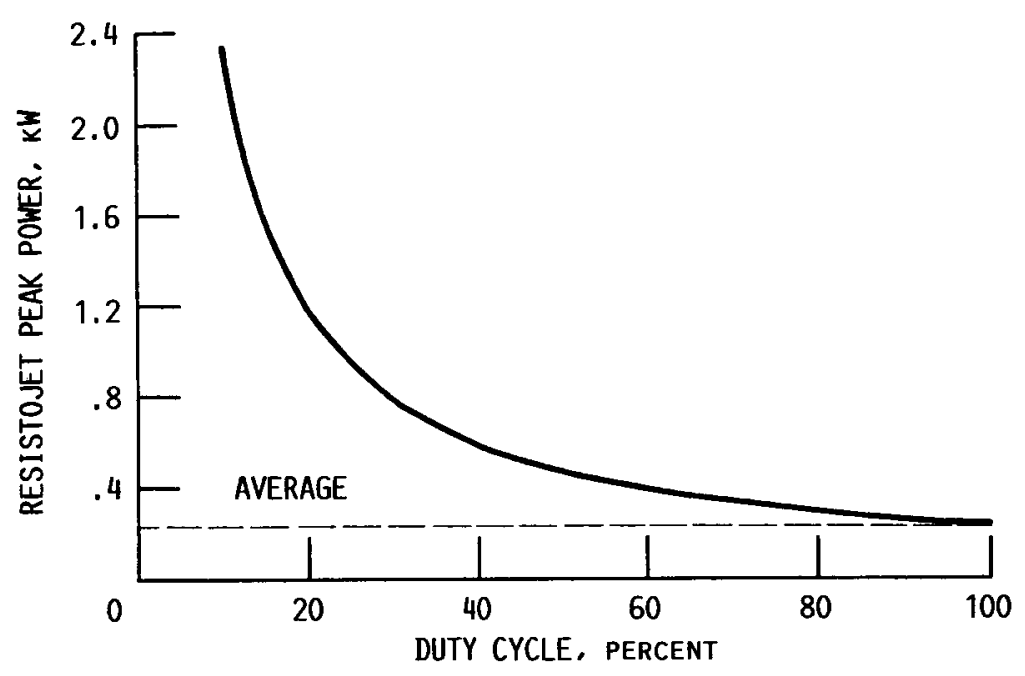

FIGURE 5. - EFFECT OF DUTY CYCLE ON PEAK RESISTOJET POWER. USING ALL IOC WASTE GASES.

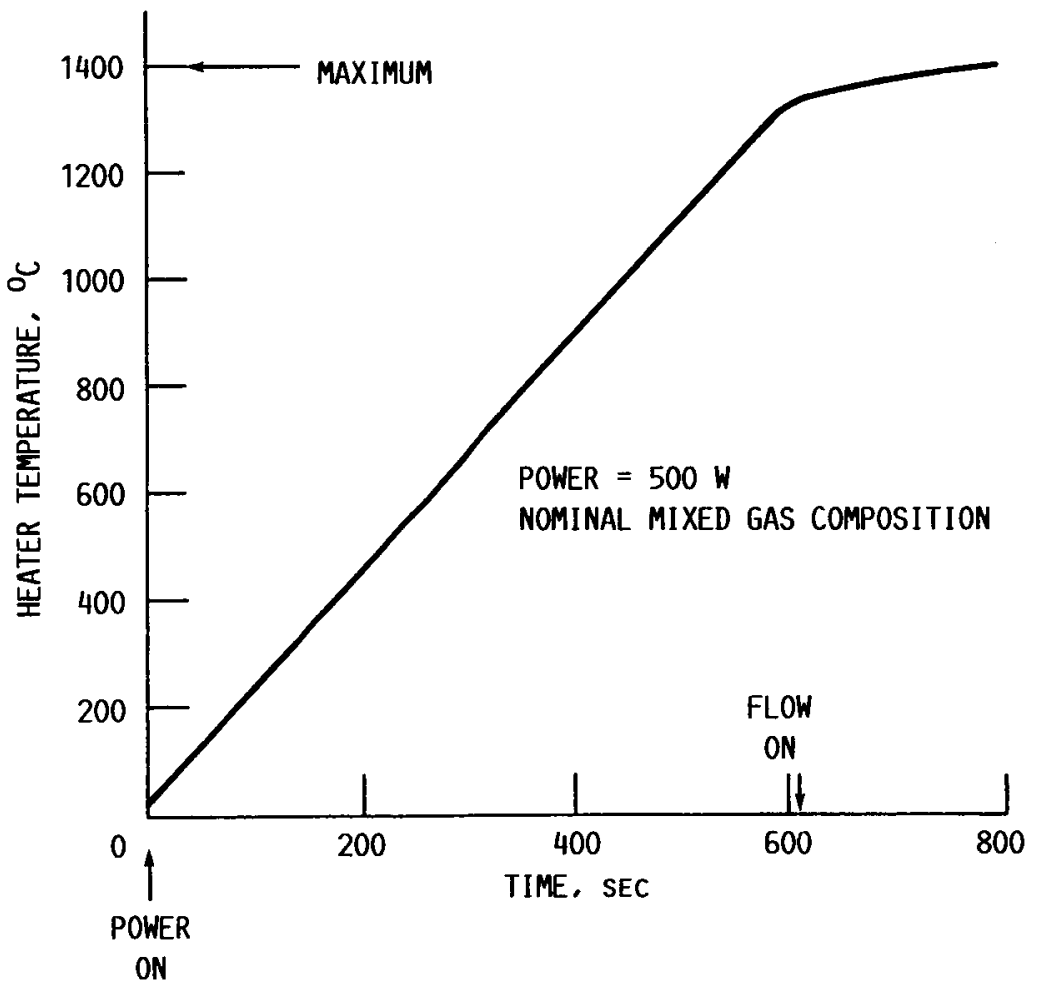

FIGURE 6. - RESISTOJET START UP TRANSIENT. 


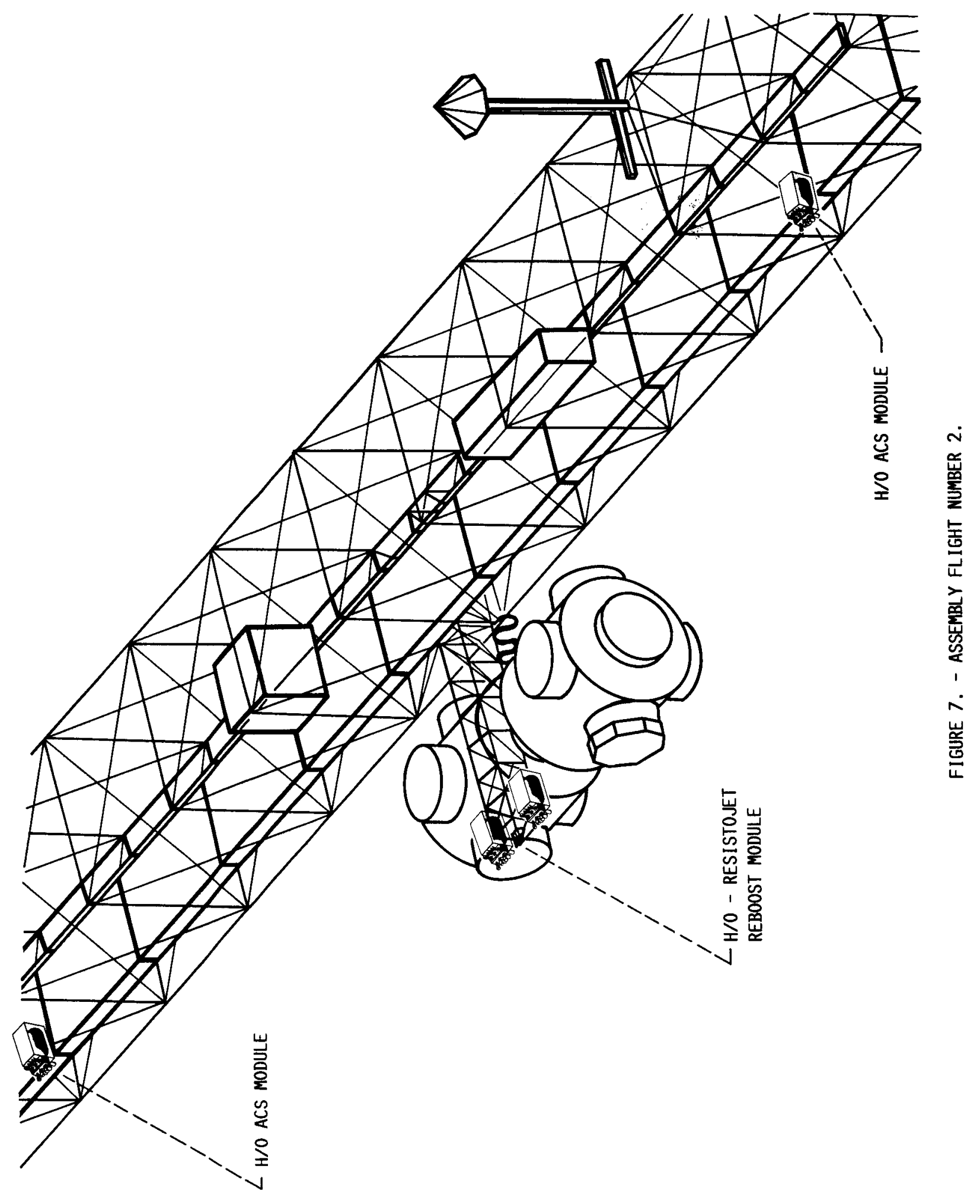


ONIGINAL PAGE IS

\section{OF POOR QUALTY}
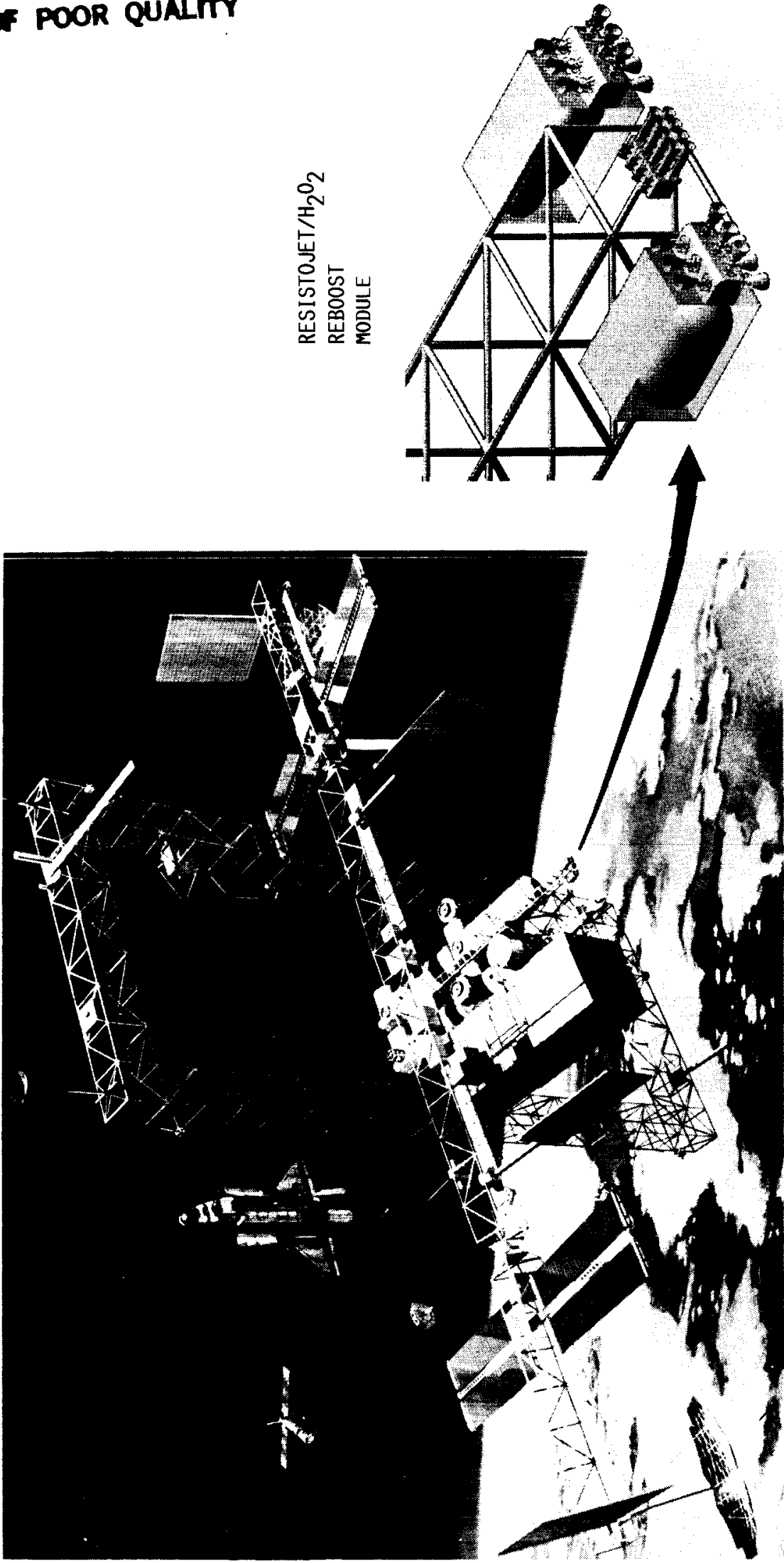

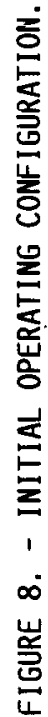




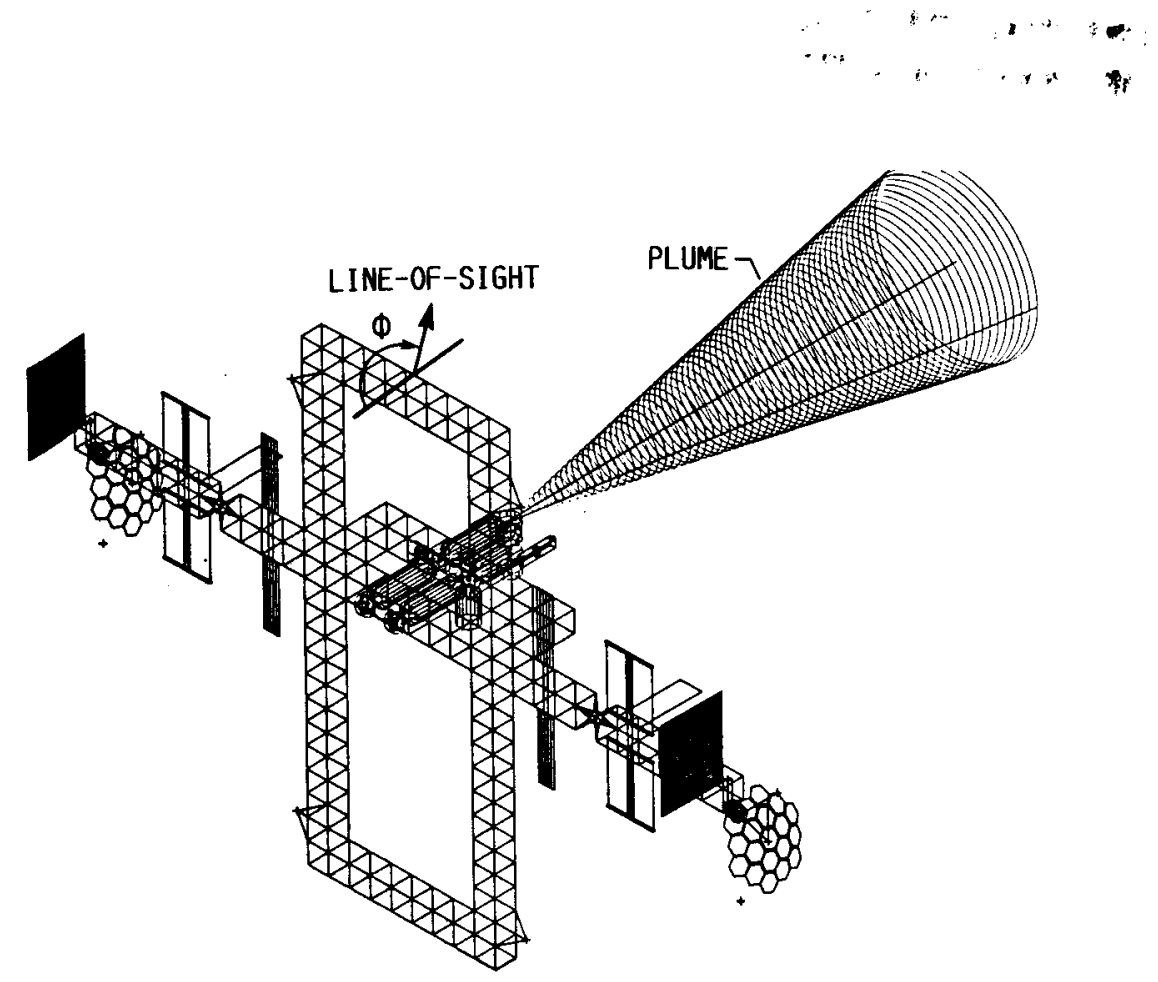

(A) LINE-OF-SIGHT REFERENCE ANGLE.

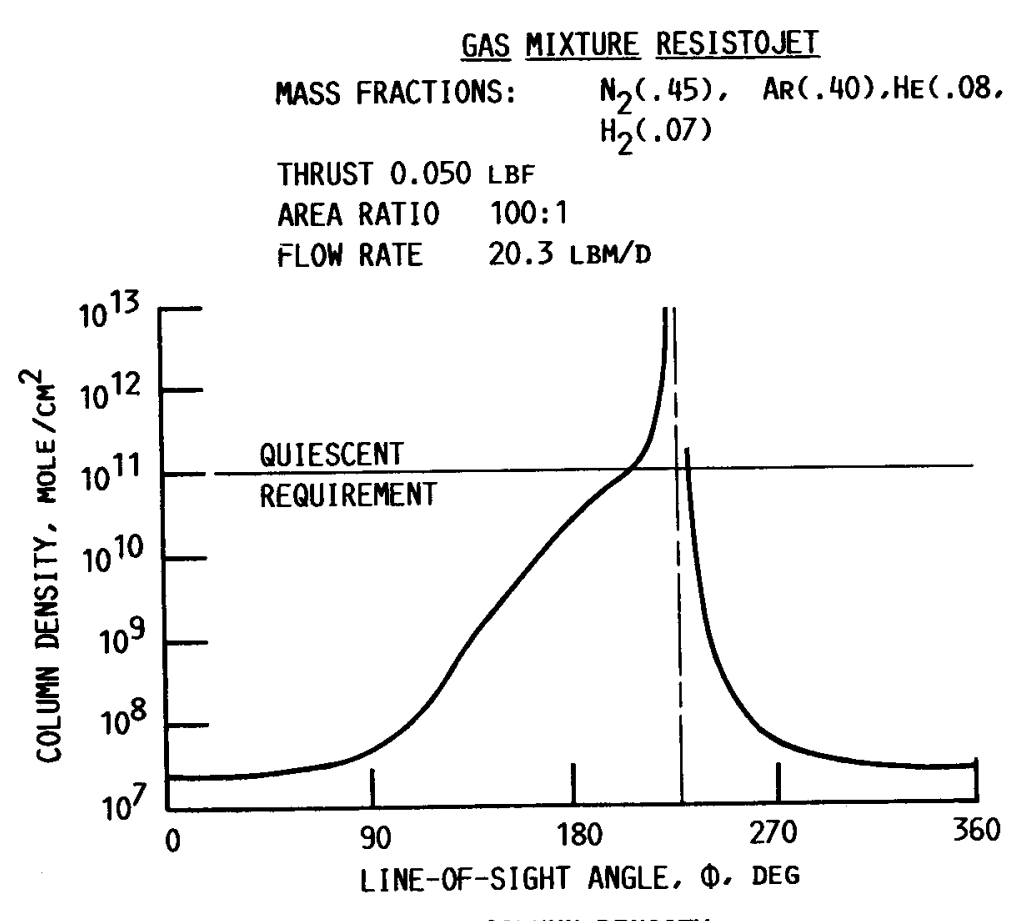

(B) COLUMN DENSITY.

FIGURE 9. - COLUMN DENSITY AS A FUNCTION OF LINE-OF-SIGHT. 


\begin{tabular}{|c|c|c|c|}
\hline $\begin{array}{l}\text { 1. Report No. } \\
\text { NASA TM-89847 }\end{array}$ & 2. Government Accession No. & \multicolumn{2}{|c|}{ 3. Recipient's Catalog No. } \\
\hline \multirow{3}{*}{\multicolumn{2}{|c|}{$\begin{array}{l}\text { 4. Title and Subtitle } \\
\text { Conceptual Design and Integration of a Space } \\
\text { Station Resistojet Propulsion Assembly }\end{array}$}} & \multirow{2}{*}{\multicolumn{2}{|c|}{ 5. Report Date }} \\
\hline & & & \\
\hline & & \multicolumn{2}{|c|}{$\begin{array}{l}\text { 6. Performing Organization Code } \\
481-02-02\end{array}$} \\
\hline \multirow{3}{*}{\multicolumn{2}{|c|}{$\begin{array}{l}\text { 7. Author(s) } \\
\text { Robert R. Tacina }\end{array}$}} & \multirow{2}{*}{\multicolumn{2}{|c|}{$\begin{array}{l}\text { 8. Performing Organization Report No. } \\
\text { E-3483 }\end{array}$}} \\
\hline & & & \\
\hline & & \multicolumn{2}{|l|}{ 10. Work Unit No. } \\
\hline \multirow{2}{*}{\multicolumn{2}{|c|}{$\begin{array}{l}\text { 9. Performing Organization Name and Address } \\
\text { National Aeronautics and Space Administration } \\
\text { Lewis Research Center } \\
\text { Cleveland, Ohio } 44135\end{array}$}} & \multirow{2}{*}{\multicolumn{2}{|c|}{ 11. Contract or Grant No. }} \\
\hline & & & \\
\hline \multicolumn{2}{|l|}{ 12. Sponsoring Agency Name and Address } & \multicolumn{2}{|c|}{$\begin{array}{l}\text { 13. Type of Report and Period Covered } \\
\text { Technical Memorandum }\end{array}$} \\
\hline \multicolumn{2}{|c|}{$\begin{array}{l}\text { National Aeronautics and Space Administration } \\
\text { Washington, D.C. } 20546\end{array}$} & \multicolumn{2}{|c|}{ 14. Sponsoring Agency Code } \\
\hline \multirow{2}{*}{\multicolumn{4}{|c|}{$\begin{array}{l}\text { 15. Supplementary Notes } \\
\text { Prepared for the 23rd Joint Propulsion Conference, cosponsored by the AIAA, SAE, } \\
\text { ASME, and ASEE, San Diego, California, June } 29-\text { July } 21,1987 \text {. }\end{array}$}} \\
\hline & & & \\
\hline \multicolumn{4}{|c|}{$\begin{array}{l}\text { 16. Abstract } \\
\text { The resistojet propulsion module is designed as a simple, long life, low risk } \\
\text { system that offers operational flexibility to the Space. Station Program. It can } \\
\text { dispose of a wide variety of typical Space Station waste fluids by using them as } \\
\text { propellants for orbital maintenance. A high temperature mode offers reiatively } \\
\text { high specific impulse with long life while a low temperature mode can propul- } \\
\text { sively dispose of mixtures that contain oxygen or hydrocarbons without reducing } \\
\text { thruster life or generating particulates in the plume. A low duty cycle and a } \\
\text { plume that is confined to a small aft region minimizes the impacts on the users. } \\
\text { simple interfaces with other Space Station systems facilitate integration. It is } \\
\text { concluded that there are no major obstacles and many advantages to developing, } \\
\text { installing and operating a resistojet propulsion module aboard the Initial opera- } \\
\text { tional Capability (IOC) Space station. }\end{array}$} \\
\hline \multirow{2}{*}{$\begin{array}{l}\text { 17. Key Words (Suggested by Author(s)) } \\
\text { Resistojet } \\
\text { Space Station propulsion }\end{array}$} & & \multirow{2}{*}{\multicolumn{2}{|c|}{$\begin{array}{l}\text { 18. Distribution Statement } \\
\text { Unc lassified - un limited } \\
\text { STAR Category } 20\end{array}$}} \\
\hline & $\begin{array}{l}\text { Unc } 7 \\
\text { STAR }\end{array}$ & & \\
\hline $\begin{array}{l}\text { 19. Security Classif. (of this report) } \\
\text { Unc las s if fed }\end{array}$ & $\begin{array}{l}\text { 0. Security Classif. (of this page) } \\
\text { Unc las s if i ed }\end{array}$ & $\begin{array}{c}\text { 21. No. of pages } \\
17\end{array}$ & $\begin{array}{r}\text { 22. Price* } \\
\mathrm{A} 02\end{array}$ \\
\hline
\end{tabular}

*For sale by the National Technical Information Service, Springfield, Virginia 22161 